Journal of Animal and Veterinary Advances 11 (13): 2347-2351, 2012

ISSN: $1680-5593$

(C) Medwell Journals, 2012

\title{
Effect of Iron Supplement on the Activity of Catalase, SDH and Their MRNA Expression in Rex Rabbit
}

\author{
Zhao-Qin Zhang, Xiang-Ru Zhao, Jun-Feng Lian, Li-Hui Guan and Hai-Wang Zhang \\ College of Animal Science and Technology, \\ Hebei North University, 075131 Zhangjiakou, P.R. China
}

\begin{abstract}
The effect of iron (Fe) supplement on the activity of Catalase (CAT) and Sorbitol Dehydrogenase $(\mathrm{SDH})$ in blood and their mRNA expressions in liver cells of rex rabbits were evaluated. The rabbits were fed with basal diets supplemented with $0,30,60,90,120,150$ and $200 \mathrm{mg} \mathrm{kg}^{-1}\left(\mathrm{FeSO}_{4} \mathrm{H}_{2} \mathrm{O}\right)$, respectively for 60 days. The added Fe significantly increased the activity of CAT and SDH in blood compared to controls $\left(0 \mathrm{mg} \mathrm{kg}^{-1}\right)$ but the amount added had little effect. Adding Fe at $30,60,90,120,150$ and $200 \mathrm{mg} \mathrm{kg}^{-1}$ upregulated CAT gene expression by $45,58,67,64,61$ and $63 \%$, respectively. The corresponding gene upregulation for SDH were 41 , $59,71,69,67$ and $68 \%$. Fe supplement also increased the average daily weight gain and fresh fur areas. All the measurements reached a plateau around $90-120 \mathrm{mg} \mathrm{kg}^{-1}$ added $\mathrm{Fe}$. The information provides a valuable reference to diet formulation optimization specifically for Rex rabbits.
\end{abstract}

Key words: Iron, enzymes, rabbit, SDH mRNA, CAT mRNA, China

\section{INTRODUCTION}

Rex rabbit is a domestic rabbit breed with a dense and plush coat. It is raised as pets or farmed for economical gains in many areas around the world. In recent years, Rex rabbits are popular among small farm owners and large producers in China for fur and meat production (Liu, 2011). The popularity has stimulated a number of researches on improving production performance through balanced nutrition and dietary supplements such as crude fiber and proteins (Gu et al., 2008; Li et al., 2009; Shen et al., 2009). Currently most Rex rabbit producers are using nutritional standards recommended for either rabbit meat or fur productions in general. Feed standards or optimal levels of micro-minerals requirements have not been established specifically for rex rabbits which may greatly limit its production potentials and economic benefits (Li et al., 2009).

Iron $(\mathrm{Fe})$ is an important trace mineral that is essential to the health of animals. It is heavily involved in the synthesis of oxygen carrying proteins in blood and it also is a major constituent of many enzymes involved in the processes of energy metabolize and DNA synthesis (Reilly, 2004).

Although, $\mathrm{Fe}$ is abundant naturally in most diets its bio-availability is poor due to its reactivity and soluble chemistry nature (Cox and O'Donnell, 1981). As a result,
Fe deficiency is prevalent in certain domestic animals (Underwood, 1971) and causes anemia that directly hinders animal development and the health of immune system (Smith et al., 1944). Although, $\mathrm{Fe}$ is normally added in pre-mixed rabbit feed (Schlolaut, 1987) the proper level of supplement for Rex rabbit production has not been fully characterized.

Catalase (CAT) and Sorbitol Dehydrogenase (SDH) are two important $\mathrm{Fe}$-contain enzymes in blood. The $\mathrm{Fe}$ in CAT is directly involved in the enzymes reaction that detoxifies $\mathrm{H}_{2} \mathrm{O}_{2}$ a damaging by-product of many metabolic processes in living organisms. CAT also helps to balance free radicals and increases antioxidative activity (Cao and Yang, 2005; Ma and Feng, 2008). SDH is an important cytoplasmic enzyme in carbohydrate metabolism catalyzing the conversion of fructose to sorbitol. It also plays a role in respiratory chain reactions and active ion pump actions (Cao et al., 1996; Chen et al., 2008). The objective of this study was to evaluate the effect of dietary supplemented Fe on CAT and SDH. Their gene expressions in liver cells and levels in blood samples alone with performance characteristics were measured to provide insight information on the optimum level of iron needed. The gained information serves as a much needed reference to establish practical standard for iron requirement for Rex rabbits that could maximize production.

Corresponding Author: Zhao-Qin Zhang, College of Animal Science and Technology, Hebei North University, 075131 Zhangjiakou, P.R. China 


\section{MATERIALS AND METHODS}

Experimental animals: Healthy 50 days old Rex-rabbits obtained from the Rex rabbit Breeding Center of Quartermaster University of PLA (Changchun, China) were used in this study. Eighty four rabbits (sex ratio 1:1) were randomly divided into 7 groups according to weight and sex. Each group was further divided into 3 subgroups (replicates) of 4 rabbits (sex ratio 1:1) and maintained separately in 3 cages ( 4 rabbits cage). About 1 week before housing the rabbits, the cages were thoroughly cleaned and sterilized with alcohol touch and the cage floor was decontaminated with $1-3 \%$ cresol solution. The rabbits were acclimated in the cages for 7 days (pre-experimental period) before giving experimental diets.

Experimental diets (iron treatments): The basal diet used was pellets prepared according to the French AES standard diet for domestic rabbit that consisted of main ingredients including corn, bran, soybean hulls and corn stover and supplemented with bone meal, salt, vitamin/mineral premix and essential amino acid methionine. During the 7 days pre-experimental period, all groups were fed with this basal diet. At the end of pre-experimental period, 1 group (the control) was fed continually with the basal diet and the other 6 groups were fed with the basal diet laced with $\mathrm{FeSO}_{4} \cdot \mathrm{H}_{2} \mathrm{O}$ at levels of $30,60,90,120,150$ and $200 \mathrm{mg} \mathrm{kg}^{-1}$, respectively. The rabbits were fed 3 times (6:30, 12:30 and 18:30 h) daily ad libitum and water was available all the time. Normal standard immunization and maintenance practices were followed. The experiment ended after 60 days on the experimental diets.

Biological sample preparation and measurement: At 20 , 40 and 60 days after the experiment commenced, two rabbits with empty stomach were randomly selected from each replicates and blood samples $(5 \mathrm{~mL})$ were taken from the heart artery. Anticoagulant heparin $(0.1 \mathrm{~mL} 1 \%$ saline solution Changshan Biochemical Pharmaceutical Co. Ltd., Hebei) was added to the blood and the samples then were centrifuged at $3000 \mathrm{r} \mathrm{min}{ }^{-1}$ for $15 \mathrm{~min}$ at $4^{\circ} \mathrm{C}$. The serums were collected in Eppendorf tubes and stored under $-20^{\circ} \mathrm{C}$ until testing. At each sampling date and at the beginning of the experiment all rabbits were weighted for daily weight gain calculations. At 60 days (the end of the experiment), two rabbits were randomly selected from each replicate and immediately killed by breaking their necks. Tissue samples $(1 \mathrm{~g})$ from the same location of the livers were collected and frozen in liquid nitrogen and then transferred into a $-75^{\circ} \mathrm{C}$ refrigerator for later use. The rabbits were then completely skinned and the fur areas were measured.

Enzyme activity determination: The $\mathrm{CAT}$ and $\mathrm{SDH}$ activity of the blood samples were measured according to Feng et al. (1996) and Zhang et al. (2006), respectively. The reaction system contained $0.2 \mathrm{~mL}$ serum. All reaction reagents and solvents were provided by Great March Company (Shanghai, China). Enzyme activity was measured using a CX9 Chemistry Analyzer (Beckman Coulter Inc., Brea, CA, USA).

RNA isolation and RT-PCR: RNA isolation from the liver samples was performed according to the protocol of Trizol ${ }^{\oplus}$ reagent (Igvitrogen, Carlsbad, CA). Briefly, liver samples were homogenized with $50 \mathrm{mg} \mathrm{mL}^{-1}$ Trizol and incubated for $5 \mathrm{~min}$ under room temperature then $200 \mu \mathrm{L} \mathrm{mL}-1$ chloroform was added. After a brief vigorously shaking and incubated for $15 \mathrm{~min}$ at room temperature the samples were centrifuged $(12,000 \mathrm{~g})$ for $15 \mathrm{~min}$ at $4^{\circ} \mathrm{C}$. The supernatants were mixed with $0.5 \mathrm{~mL}$ isopropyl alcohol and incubated at room temperature for 5-10 min. Centrifuged again at $4^{\circ} \mathrm{C}$ for $10 \mathrm{~min}$. The aqueous phase was discard and RNA pellet was washed with $1 \mathrm{~mL} \mathrm{75 \%}$ ethanol and dried in air and redissolved in DEPC water.

RT-PCR of the isolated RNA was performed on a Perkin Elmer GeneAmp 9600 according to Wei et al. (2000). The primers used were designed based on GeneBank sequences and are shown in Table 1. The products were separated and identified using gelose gelatin electrophoresis and quantified using a UV spectrophotometer (721, Perkin Elmer, USA).

Data analysis: All data were analyzed by one-way ANOVA followed by fish's protected LSD for mean comparisons SPSS 11.5 was used for the analysis.

Table 1: Primer sequences used in RT-PCR

\begin{tabular}{lllc}
\hline Title of primer & Upstream primer sequence & Downstream primer sequence & Length of mpli-fication product \\
\hline$\beta$-actin & 5'-CAACACGCCGG & 5'-TCCATGCCCAGG & $420 \mathrm{bp}$ \\
& CCATGTACGT-3' & AAGGAGGGC-3' & $627 \mathrm{bp}$ \\
CAT & 5'-GTTCAGGATGTG & 5'-ACGCTGGTAGTT & \\
& GTTTCACTG-3' & GGCCACTCGAG-3' & $480 \mathrm{bp}$ \\
SDH & 5'-AGAGAAGGCATC & 5'-CAGTCATGATG & \\
& TGTGGCTCTTG-3' & GTGTGGCAGC-3' & \\
\hline
\end{tabular}




\section{RESULTS}

Effect of Fe supplement on CAT and SDH activity: The enzyme assays showed that $\mathrm{Fe}$ supplement significantly increased the activity of CAT in serum at all sample dates but the amount of $\mathrm{Fe}$ added had little effect as CAT activities were similar for all $\mathrm{Fe}$ treatments (Table 2). There was a trend that as the amount of $\mathrm{Fe}$ increased the CAT activity increased until a plateau was reached with treatments of $90 \mathrm{mg} \mathrm{kg}^{-1}$ at 20 and 60 days and $120 \mathrm{mg} \mathrm{kg}^{-1}$ at 40 days.

Similar Fe effect was observed for $\mathrm{SDH}$ activity. Added $\mathrm{Fe}$ significantly increased serum SDH activity but the amount of $\mathrm{Fe}$ had no significant effect. Plateaus were reached at the same levels as for CAT (Table 3).

Effect of Fe supplement on $C A T$ and $S D H$ gene expression: The electrophoresis results revealed that $\mathrm{Fe}$ supplement upregulated the expression of $C A T$ and $S D H$ genes (Fig. 1). CAT gene expression increased by 45,58 , $64,67,61$ and $63 \%$ compared to controls for $30,60,90,120$, 150 and $200 \mathrm{mg} \mathrm{kg}^{-1} \mathrm{Fe}$ treatments, respectively. SDH expression increases were $41,59,69,71,67$ and $68 \%$, respectively.

Figure 2 shows the dynamics of CAT and SDH mRNA expression with different level of $\mathrm{Fe}$ added. As the amount of $\mathrm{Fe}$ increased the mRNA expression increased and a plateau was reached at $90 \mathrm{mg} \mathrm{kg}^{-1}$ for both CAT and SDH. This result correlated with the dynamic of CAT and SDH activity in serums where activity plateaus were reached at 90 or $120 \mathrm{mg} \mathrm{kg}^{-1}$ of $\mathrm{Fe}$.

Table 2: Effect of iron in diet on the activity of CAT in serum $\left(\mu \mathrm{L}^{-1}\right)^{\text {t }}$

\begin{tabular}{llcc}
\hline & \multicolumn{2}{l}{ Days after treatment } & \\
$\begin{array}{l}\text { Iron added } \\
\left(\mathrm{mg} \mathrm{kg}^{-1}\right)\end{array}$ & -20 & 40 & 60 \\
\hline $0(\mathrm{control})$ & $25.83 \pm 5.68^{\mathrm{a}}$ & $26.50 \pm 4.72^{\mathrm{a}}$ & $27.23 \pm 6.24^{\mathrm{a}}$ \\
30 & $33.83 \pm 7.60^{\mathrm{b}}$ & $35.83 \pm 5.98^{\mathrm{b}}$ & $36.50 \pm 7.25^{\mathrm{b}}$ \\
60 & $35.50 \pm 6.26^{\mathrm{b}}$ & $38.67 \pm 5.85^{\mathrm{b}}$ & $40.17 \pm 6.11^{\mathrm{b}}$ \\
90 & $41.73 \pm 5.23^{\mathrm{b}}$ & $40.83 \pm 7.13^{\mathrm{b}}$ & $45.42 \pm 7.28^{\mathrm{b}}$ \\
120 & $38.83 \pm 6.92^{\mathrm{b}}$ & $43.58 \pm 7.93^{\mathrm{b}}$ & $43.67 \pm 6.69^{\mathrm{b}}$ \\
150 & $40.96 \pm 7.29^{\mathrm{b}}$ & $41.36 \pm 7.57^{\mathrm{b}}$ & $45.32 \pm 6.12^{\mathrm{b}}$ \\
200 & $39.33 \pm 6.31^{\mathrm{b}}$ & $40.34 \pm 4.32^{\mathrm{b}}$ & $44.33 \pm 5.18^{\mathrm{b}}$ \\
$\mathrm{F}, \mathrm{p}$ & $26.07,0.0082$ & $51.58,0.0076$ & $53.37,0.0085$ \\
\hline
\end{tabular}

Table 3: Effect of iron in diet on the activity of SDH in serum $\left(\mu \mathrm{L}^{-1}\right)^{*}$

\begin{tabular}{lccc}
\hline & \multicolumn{2}{c}{ Days after treatment } & \\
$\begin{array}{l}\text { Iron added } \\
\left(\mathrm{mg} \mathrm{kg}^{-1}\right)\end{array}$ & - & 40 & 60 \\
\hline $0($ control $)$ & $21.00 \pm 4.84^{\mathrm{a}}$ & $22.33 \pm 6.26^{\mathrm{a}}$ & $22.98 \pm 6.81^{\mathrm{a}}$ \\
30 & $28.20 \pm 5.02^{\mathrm{b}}$ & $29.00 \pm 6.33^{\mathrm{b}}$ & $30.83 \pm 5.83^{\mathrm{b}}$ \\
60 & $30.38 \pm 5.88^{\mathrm{bc}}$ & $31.67 \pm 6.82^{\mathrm{b}}$ & $31.82 \pm 7.19^{\mathrm{b}}$ \\
90 & $34.67 \pm 7.20^{\mathrm{b}}$ & $35.47 \pm 7.11^{\mathrm{b}}$ & $36.67 \pm 6.97^{\mathrm{b}}$ \\
120 & $32.83 \pm 6.11^{\mathrm{b}}$ & $36.12 \pm 6.47^{\mathrm{b}}$ & $33.33 \pm 7.24^{\mathrm{b}}$ \\
150 & $31.56 \pm 6.26^{\mathrm{b}}$ & $33.89 \pm 7.14^{\mathrm{b}}$ & $34.17 \pm 6.06^{\mathrm{b}}$ \\
200 & $30.50 \pm 6.65^{\mathrm{bc}}$ & $33.23 \pm 6.27^{\mathrm{b}}$ & $30.87 \pm 7.56^{b}$ \\
$\mathrm{~F}, \mathrm{p}$ & $21.46,0.0078$ & $26.22,0.0083$ & $28.15,0.0074$ \\
\hline
\end{tabular}

*Means \pm SD $(n=4)$ followed by different superscript letters were significantly different ( $p<0.05$, LSD) within each sample date
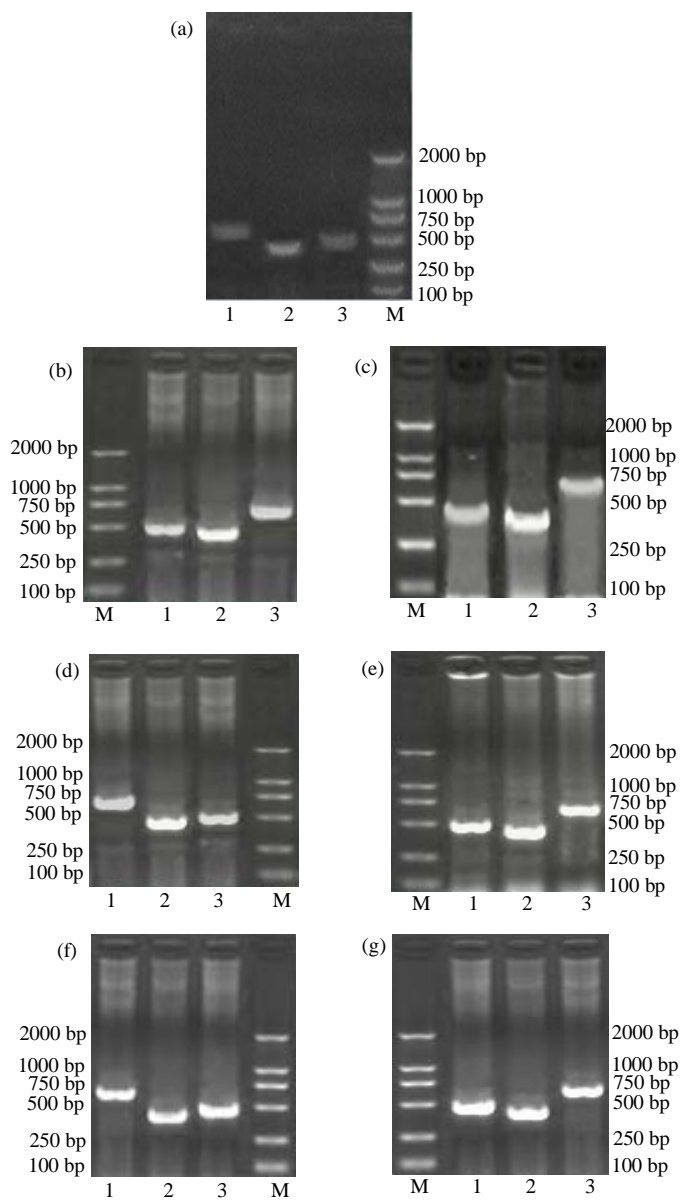

Fig. 1: Gelose gelatin electrophoresis (1\%) of RT-PCR production with different iron treatments: a) control; b) $30 \mathrm{mg} \mathrm{kg}^{-1}$ iron; c) $60 \mathrm{mg} \mathrm{kg}^{-1}$ iron; d) $90 \mathrm{mg} \mathrm{kg}^{-1}$ iron; e) $120 \mathrm{mg} \mathrm{kg}^{-1}$; f) $150 \mathrm{mg} \mathrm{kg}^{-1}$; g) $200 \mathrm{mg} \mathrm{kg}^{-1}$ iron; 1 : CAT; 2 : $\beta$-actin; 3 : SDH and M: Marker DL2000
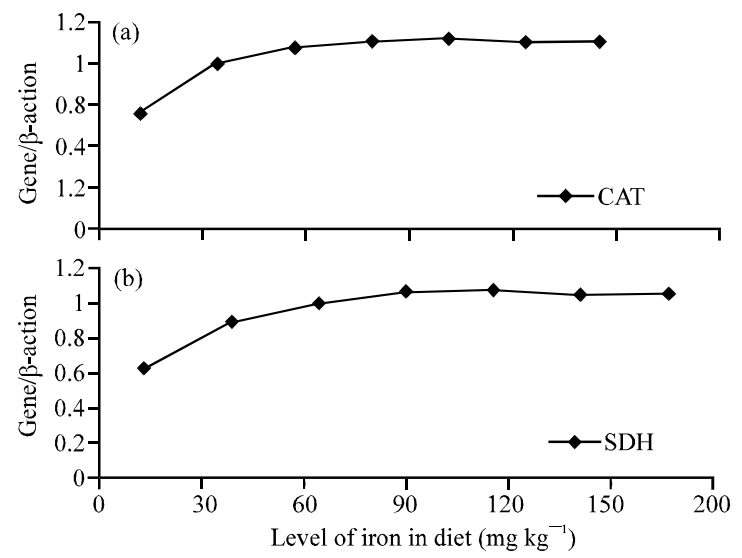

Fig. 2: The expression of mRNA of CAT and SDH in tissues of the Rex rabbits at different iron levels 
Table 4: Effect of level of iron in diet on daily weight gain (g) and fur area $\left(\mathrm{cm}^{2}\right)^{*}$

\begin{tabular}{|c|c|c|c|c|}
\hline \multirow{2}{*}{$\begin{array}{l}\text { Iron added } \\
\left(\mathrm{mg} \mathrm{kg}^{-1}\right)\end{array}$} & \multicolumn{3}{|c|}{ Average daily weight gain (g) } & \multirow[b]{2}{*}{$\begin{array}{c}\text { Fur area at } 60 \\
\text { days }\left(\mathrm{cm}^{2}\right)\end{array}$} \\
\hline & 20 days & 40 days & 60 days & \\
\hline 0 (control) & $16.96 \pm 2.85^{\mathrm{a}}$ & $15.93 \pm 3.58^{\mathrm{a}}$ & $13.60 \pm 4.36^{a}$ & $977 \pm 202^{\mathrm{a}}$ \\
\hline 30 & $19.18 \pm 3.92^{b}$ & $19.34 \pm 3.24^{b}$ & $16.09 \pm 4.22^{b}$ & $1119 \pm 229^{b}$ \\
\hline 60 & $20.95 \pm 3.75^{b}$ & $20.86 \pm 4.07^{b}$ & $19.97 \pm 3.16^{b}$ & $1026 \pm 180^{b}$ \\
\hline 90 & $22.08 \pm 4.75^{b}$ & $22.03 \pm 3.63^{b}$ & $21.12 \pm 4.93^{b}$ & $1198 \pm 145^{b}$ \\
\hline 120 & $21.33 \pm 3.86^{b}$ & $23.11 \pm 3.18^{b}$ & $20.20 \pm 5.48^{b}$ & $1202 \pm 276^{b}$ \\
\hline 150 & $19.63 \pm 3.82^{b}$ & $20.60 \pm 4.83^{b}$ & $18.51 \pm 5.59^{b}$ & $1058 \pm 124^{b}$ \\
\hline 200 & $19.09 \pm 4.22^{b}$ & $19.76 \pm 4.83^{b}$ & $17.43 \pm 5.37^{b}$ & $1177 \pm 135^{b}$ \\
\hline$\underline{F, p}$ & $18.78,0.0079$ & $19.12,0.0081$ & $16.67,0.0076$ & $562.48,0.0086$ \\
\hline
\end{tabular}

*Means \pm SD $(n=4)$ followed by different superscript letters were significantly different $(p<0.05, \mathrm{LSD})$ within each sample date

Effect of Fe supplement on daily weight gain and fur area: Iron supplement affected the daily weight gain. The average daily weight gain increased as the $\mathrm{Fe}$ level increased. Similar to the measured biochemistry parameters average daily gain reached a plateau at $90-120 \mathrm{mg} \mathrm{kg}^{-1}$ levels (Table 4). The Fe effect on fresh fur area was similar as on weight gain. Adding $\mathrm{Fe}$ significantly increased the fur area compared to the control but the amount of $\mathrm{Fe}$ had little effect. The maximum fur area occurred at $120 \mathrm{mg} \mathrm{kg}^{-1}$.

\section{DISCUSSION}

The current study intended to address the effect of dietary $\mathrm{Fe}$ supplement on $\mathrm{Rex}$ rabbit production at a molecular level. The data indicated that adding $\mathrm{Fe}$ significantly increased the gene expressions of two major $\mathrm{Fe}$-contain enzymes CAT and SDH and this upregulation was directly reflected in higher levels of CAT and SDH activities in the blood. Sufficient CAT and SDH are essential for the health of animals. Reasonable higher levels of them will favorably affect animal metabolism and development consequently improve the production potential of domestic animals such as rex rabbits.

All measured biochemistry and production performance parameters showed a common trend. As the level of added $\mathrm{Fe}$ increased the measurements increased and researched a plateau at $90-120 \mathrm{mg} \mathrm{kg}^{-1}$ depending on the sample dates. The sample date effect suggests that optimal Fe levels may be different depending on the animals' developmental stages. Previous studies also showed that adding $\mathrm{Fe}$ was positively correlated with enzyme activity within a certain range of $\mathrm{Fe}$ amounts (Wei et al., 1999; Zhang et al., 2006). This general phenomenon reflects a common kinetic in Fe absorption and utilization by animals (Forth and Rummel, 1973). As $\mathrm{Fe}$ accumulates in the body the limited binding sites for $\mathrm{Fe}$ are saturated. The lack of dose response observed in this study could be an indication of binding saturation. Therefore, the beneficial effect of Fe supplement will diminish at certain amounts and may even cause adverse effect by interfering with the absorption of other nutrients such as $\mathrm{P}, \mathrm{Cu}$ and $\mathrm{Mn}$ (Sun et al., 2010). Literatures reported a wide range of $\mathrm{Fe}$ requirements for rabbits from 30-129 ppm (El-Masty and Nasr, 1996; Mateos and de Blas, 1998).

\section{CONCLUSION}

The current study provides a useful and practical reference in determining the optimal level of Fe dietary supplement specifically for rex rabbits so that the economic benefit can be maximized.

\section{ACKNOWLEDGEMENTS}

The researchers would like to thank anonymous reviewers for their critical comments on the manuscript.

\section{REFERENCES}

Cao, J., X.G. Luo, P.R. Henry, C.B. Ammerman, R.C. Littell and R.D. Miles, 1996. Effect of dietary iron concentration, age and length of iron feeding on feed intake and tissue iron concentration of broiler chicks for use as a bioassay of supplemental iron sources. Poult. Sci., 75: 495-504.

Cao, S. and L. Yang, 2005. Effect of the diet with highselenium and -iron on SOD, GOT and GPT activities of plasma and liver homogenate of laying hen. J. Anhui Agric. Sci., 12: 17-19.

Chen, S., X. Shuai and Y. Qiu, 2008. Effects of Fe-(3+) on membrane lipid peroxidation and activity of endogenous protective enzymes in Trotary Buckwheat. Acta Agric. Boreali-Occidentalis Sinaca, 1: 23-24.

Cox, T.M. and M.W. O'Donnell, 1981. Studies on the binding of iron by rabbit intestinal microvillus membranes. Biochem. J., 194: 753-759.

El-Masry, K.A. and A.S. Nasr, 1996. The role of folic acid and iron in reproductive performance of New Zealand white does and their kits. World Rabbit Sci., 4: 127-131. 
Feng, G., Q. Cui and A. Feng, 1996. Colorimentry determination of serum catalase activity. Shanxi J. Med. Lab. Sci., 4: 26-28.

Forth, W. and W. Rummel, 1973. Iron absorption. Physiol. Rev., 53: 724-792.

Gu, Z., B. Chen, J. Li, J. Ge, Y. Huang and Y. Liu, 2008. Effect of $\mathrm{CF}$ level on the growth performance and nutrient digestibility of rex rabbit. J. Agric. Univ. Hebei, 1: 71-74.

Li, Q., Y. Cui, Z. Wu and W. Zhang, 2009. The research status on the nutrition of Rex rabbit. Grass-Feeding Livestock, 4: 47-50.

Liu, A., 2011. The measures and experience of developing rex rabbits industry in Linzhang county. Chinese J. Anim. Sci., 2: 60-62.

Ma, W. and J. Feng, 2008. Effects of glycine chelate on oxidative enzymes and parameters in serum of eeaned piglets. Feed Ind., 22: 11-13.

Mateos, G.G. and C. de Blas, 1998. Minerals, Vitamins and additives. In: The Nutrition of the Rabbits, De Blas, C. and J. Wiseman (Eds.)., CABI Publishing, CAB International, UK., pp: 145-176.

Reilly, C., 2004. The Nutritional Trace Metals. Blackwell Publishing, Oxford, UK and Ames, Iowa, pp: 35-81.

Schlolaut, W., 1987. Nutritional needs and feeding of German Angora Rabbits. J. Appl. Rabbit Res., 10: $111-121$.
Shen, F., Z. Ren, Y. Lin, B. Guo and Y. Gao et al., 2009. The influence of different dietary crude protein and digestible energy levels on production performance of Rex rabbit. Acta Agric. Boreali-Occidentalis Sinic, 6: 86-89.

Smith, S.E., M. Medlicot and G.H. Ellis, 1944. The blood picture of iron and copper deficiency anemias in the rabbit. Am. J. Physiol., 142: 179-181.

Sun, X., C. Li, X. Yang, Y. Liu, H. Li and J. Yao, 2010. Effects of supplementing copper, iron, zinc and manganese on the growth performance of broilers. Acta Agric. Boreali-Occidentalis Sinica, 3: 31-35.

Underwood, E.J., 1971. Trace Elements in Human and Animal Nutrition. 3rd Edn., Academic Press, New York and London, pp: 14-56.

Wei, X., S. Li and X. Dong, 1999. The effects of Fe and Zn on the piglet's growth, physiological and biochemical parameter. J. Nanjing Agric. Univ., 22: 113-115.

Wei, X., Y. Zhang and J. Zhou, 2000. Quantitative determination of alzheimer's disease related gene expression in the brain of mice by RT PCR. Bull. Acad. Military Med. Sci., 2: 110-113.

Zhang, Z., W. Ren, J. Zhang and Y. Wang, 2006. Effect of different iron levels in diet of JirongIRONG II Rex rabbit on its blood enzyme activity. J. Jilin Agric. Univ., 4: 433-435. 